$\mathbb{T}$ periodica polytechnica

Mechanical Engineering

$53 / 1$ (2009) 13,17

doi: 10.3311/pp.me.2009-1.02

web: http://www.pp.bme.hu/me

(c) Periodica Polytechnica 2009

RESEARCH ARTICLE

\section{Emissions at airports and their impact at the habitat}

Michael Palocz-Andresen

Received 2009-01-18

\section{Abstract}

One of the most important problems in air traffic is the production of air pollutants at and near airports. The estimation can be made today with help of calculation methods and measuring techniques. In most cases, calculations lead to a usable approach, but considering the intensive development of air traffic, measurement technologies are growing in importance.

To reduce the high concentration of pollutants in the atmosphere, airports have to consider four sources:

fleet operation

in-house energy supply

ground feeder traffic of motor vehicles

catering and supply services for airports.

This system measures emissions during flight events (take off, landing and runway operations) from airplanes and from other airport specific sources. This very precise method makes it possible to compare this data with the calculated emissions (LASPORT) of air pollutants in the big area of airports. This combined method is much more accurate, than the single mathematical modelling of emissions and their distribution. This method leads to a much improved accuracy of planning of airports and air traffic near and at airports compared with the current situation.

\section{Keywords}

Age of airplane - air pollution - air traffic $\cdot$ airplane engine . emission analyser $\cdot$ apron area $\cdot$ auxiliary power unit $\cdot$ calculation of the exhaust gas emissions · take off · landing · runway operation

\section{Emissions and distribution of pollutants at airports}

Air pollution caused by human activities shows its unfavourable effects in different ways in the ecosphere and on the earth's climate. Airplane engines produce a lot of different combustion products; see Fig. 1][1].

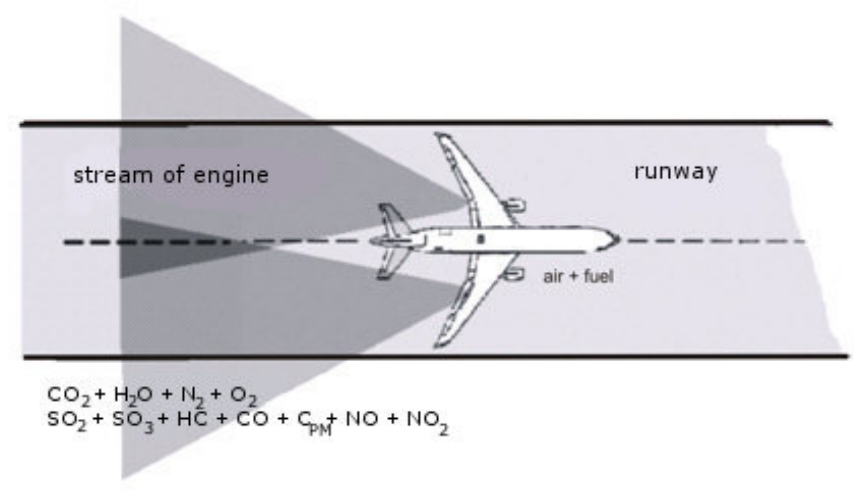

Fig. 1. Output of pollutants and climate gases into the atmosphere

The concentration, the mass stream and the distribution of pollutants depend above all on the altitude of the airplanes; see Fig. 2][2].

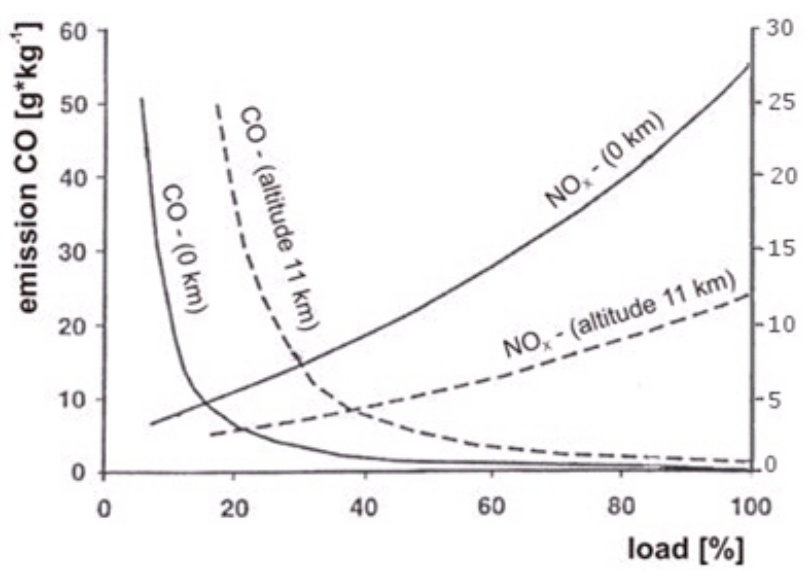

Fig. 2. Emissions depending on the altitude by the engine type CF 6-80

This report considers only the distribution of gases near the ground.
Michael Palocz-Andresen

NyME, 9400 Sopron Bajcsy Zs. u. 4, Hungary 
2 Mobile emission measurements at the airport on the ground

For monitoring of the limiting values the device was equipped with novel electrochemical cells, with an infrared optical and a photo ionisation detector; see Fig. 3

In Table 1 the measurements refer to the individual types of gas [3].

Tab. 1. Characteristics of the modified measurement device

\begin{tabular}{|c|c|c|}
\hline type of gas & $\begin{array}{l}\text { measurement } \\
\text { in ppm }\end{array}$ & Procedure \\
\hline carbon monoxide CO & $0.5 \mathrm{ppm}=500 \mathrm{ppb}$ & electro chemistry \\
\hline nitrogen monoxide NO & $0.1 \mathrm{ppm}=100 \mathrm{ppb}$ & electro chemistry \\
\hline carbon dioxide $\mathrm{CO}_{2}$ & 100 ppm & infrared absorption \\
\hline unburned hydrocarbons HC & $1 \mathrm{ppm}$ & photo ionisation \\
\hline
\end{tabular}

\subsection{Air traffic emissions during the LTO cycle}

The international basis for the calculation of exhaust gas emissions is the actual daily traffic data of commercial flights. In the standardized Landing-Take Off cycle (LTO cycle), introduced by the ICAO, four different operation states with different impulse levels and time fractions are defined: (idle 26 minutes, approach 4 minutes, take off 0.7 minutes and climb 2.2 minutes). The standardized LTO cycle is based on large American traffic airports and therefore specifies an average 26 minutes idle time. This is not realistic for European airports because of their smaller size.

At European airports the average runway time, from landing until final stopping, is approximately 4 minutes and the time from start of rolling until take off is 11.7 minutes.

To determine emissions the actual runway time for each airplane is considered accordingly to traffic statistics. The observation limit of the LTO cycle is approximately 3,000 ft(=915 m) altitude [4].

\subsection{Emissions of the APU (auxiliary power unit) und GPU (ground power unit)}

Airplanes need energy to operate their systems while on the ground. Energy is needed to operate the electronic systems of the airplane, and for heating and cooling the cabin, the cockpit and the cargo compartment. This energy can be provided to the airplanes through internal and external systems. The gates are equipped with an APU. The outer positions can be nearly completely equipped with GPU's. In reality we can assume 80 $\%$ of power the supply comes from the outer positions.

\subsection{Fuelling emissions}

Evaporation emissions occur during refuelling of the airplanes, and we can assume an average volume of $6.31 \mathrm{~m}^{3}$ kerosene per airplane. With the above mentioned emission fac- tor, we calculated an average refuelling emission of $47.3 \mathrm{~g} \mathrm{HC}$ per airplane.

\subsection{Emissions at the apron area}

There are additional sources of emissions at the airport such as crew buses, luggage conveyor belts, loading trolleys, lift platforms etc.

These emissions arise from activities which support the flights. In addition to pollution on the apron, there is driving on main roads which can not be allocated to the flight movements. With the help of random measurements, we estimate the daily number of motor vehicles, private cars, light commercial and heavy duty vehicles.

\subsection{Emissions through heating and power systems}

Airports control several heating and power systems, and heating systems usually generate over $92 \%$ of the total heating power. They are mainly operated by natural gas. At the request of the public services, they can be changed to light fuel oil.

\subsection{Emissions of ground traffic of passengers, visitors and} employees, of the tanker lorries, and of freight traffic

Many passengers use private cars to reach the airport instead of using public transport. Approximately $3 \%$ of the passengers transfer from other flights. About $15 \%$ arrive with their own motor vehicles, $40 \%$ are taken to the airport, $4 \%$ arrive in a rented car and $19 \%$ take a taxi. Approximately $78 \%$ of the employees use a private motor vehicle. It is assumed that only one person is sitting in a car. Fuel for the tank farm is exclusively delivered by road tankers. Air cargo is also delivered by motor vehicles.

\section{Results of the measurement of emissions at the air- port}

The resulting emissions in the airport area show high $\mathrm{NO}_{x}$ and $\mathrm{CO}$ concentrations:

- unburned hydro carbons (HC) $6.0 \%$

- nitrogen monoxide $\left(\mathrm{NO}_{x}\right) 50.0 \%$

- carbon monoxide (CO) $40.0 \%$

- others $4.0 \%$.

Air traffic causes the greatest amount of pollutants, approximately $82 \%$.

$18 \%$ come from other sources as APU, GPU, apron, combined heat and power stations.

Most emissions are produced by smaller airplanes; see Fig. 4 The portions of the individual exhaust gas components are different in the discrete flight phases; see Fig. 5 .

The phases contribute to the emission as follows:

- idle $57 \%$

- approach $12 \%$ 


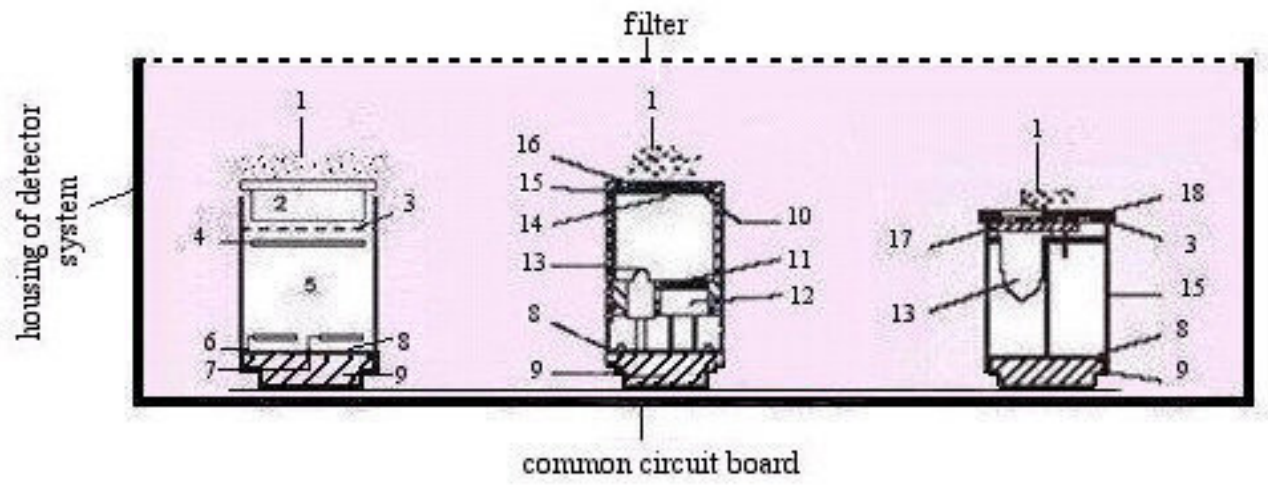

$\begin{array}{ll}1 \text { measured gas } & 10 \text { ex-protection rack } \\ 2 \text { selective filter } & 11 \text { window } \\ 3 \text { membrane } & 12 \text { detector } \\ 4 \text { sensing electrode } & 13 \text { lamp } \\ 5 \text { electrolyte } & 14 \text { reflector } \\ 6 \text { reference electrode } & 15 \text { housing of cell } \\ 7 \text { counter electrode } & 16 \text { sealing area } \\ 8 \text { circuit board with EE-prom } & 17 \text { ionisation cell } \\ 9 \text { socket } & 18 \text { insulation }\end{array}$

Fig. 3. Functional principle of the mobile measuring system

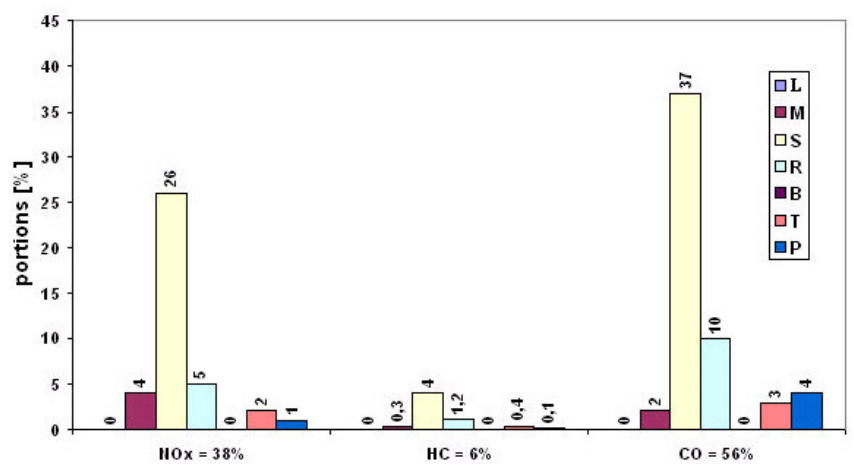

$\mathrm{L}$ large $\mathrm{M}$ middle $\mathrm{S}$ small $\mathrm{R}$ regional $\mathrm{B}$ business $\mathrm{T}$ turboprop $\mathrm{P}$ propeller

Fig. 4. Emissions at airport area as a function of airplane size

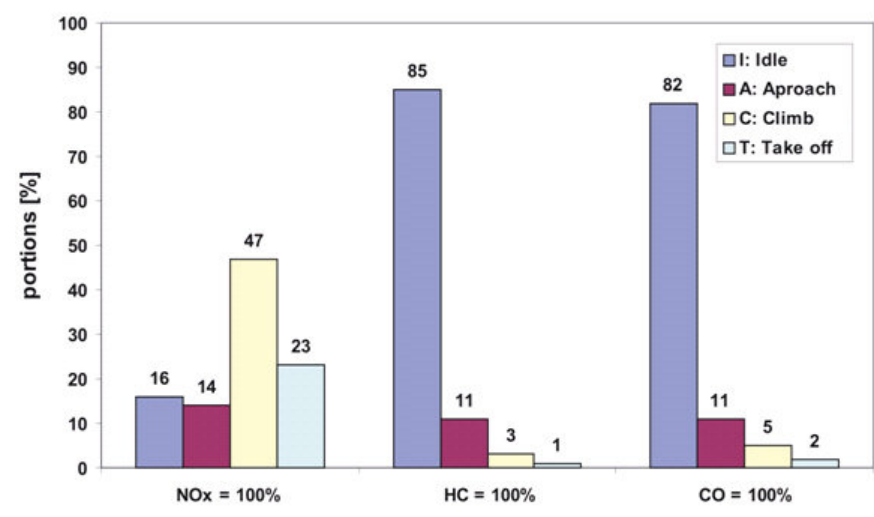

Fig. 5. Portions of exhaust gas components in the individual flight phases

- $\operatorname{climb} 21 \%$

- take off $10 \%$.

Considering the amounts of ejected pollutants in the individual operation phases of flight, small airplanes emit the most pollutants. During the idle phase, the most $\mathrm{CO}$ and $\mathrm{HC}$ are produced. The climb phase is the second largest source of these

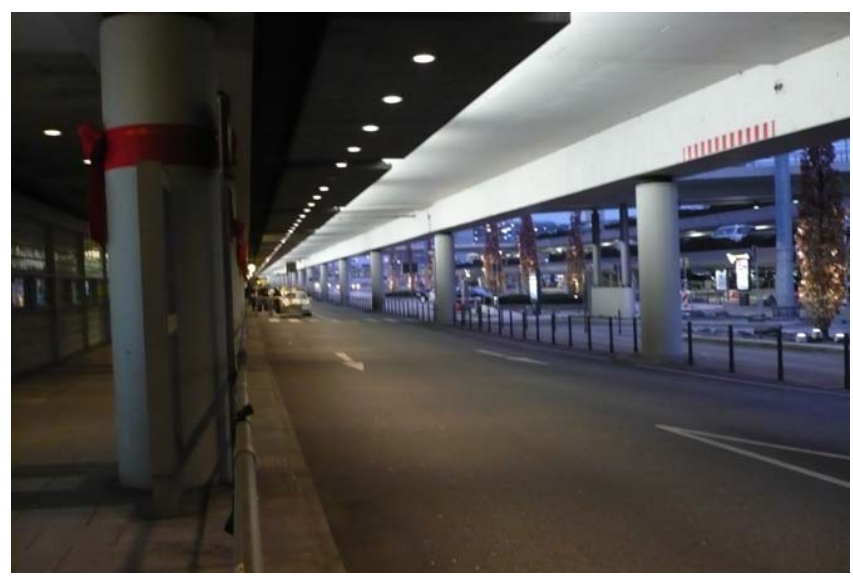

Fig. 6. View of the access road by the terminals in Hamburg

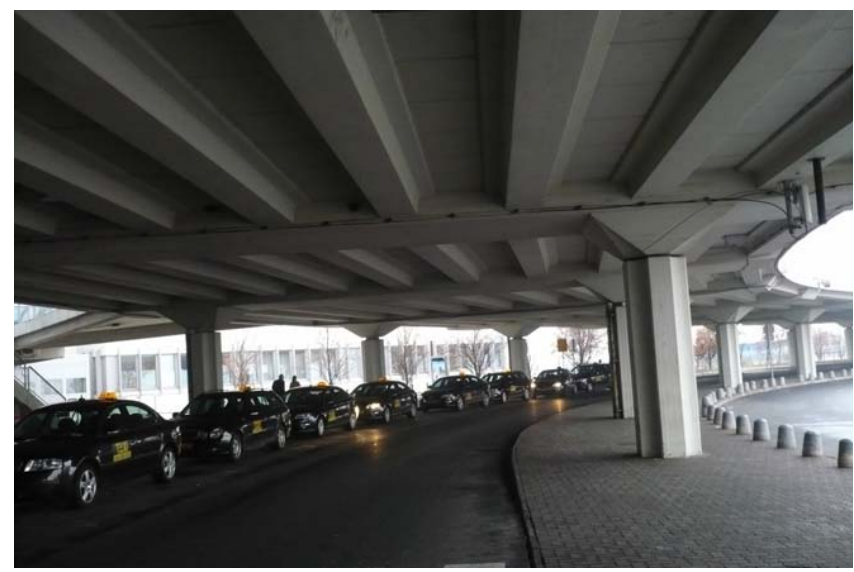

Fig. 7. Covered road in front of the terminals at the Budapest airport

pollutants. During the approach and take off operation phases ca. $20 \%$ of pollutants are emitted [5]. 
Fig. 8. High concentration of pollutants in the area of access roads and parking garages

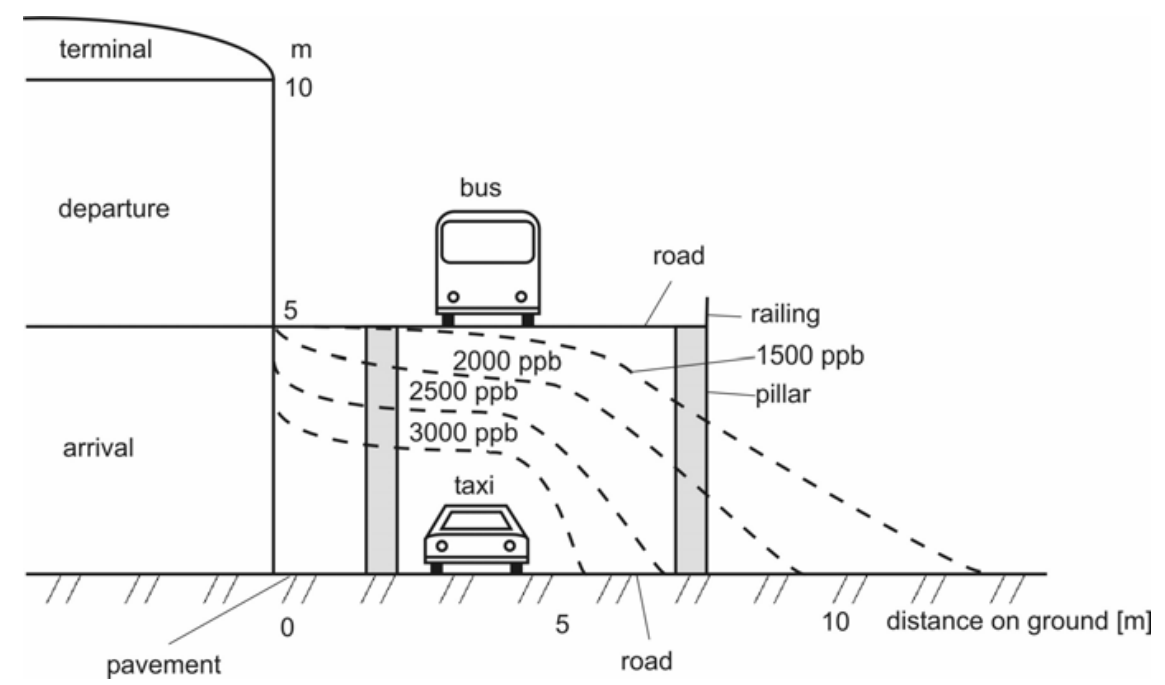

\section{Conclusions from the measurement of the emissions}

\subsection{Distribution of pollutants}

It is impossible to measure emissions from airplanes in the climb phase because of their strong propulsion forces. The lateral measurement causes no difficulties since the jet exhaust flows quickly diminish perpendicular to the propulsion axis [6]. This determination applies to calm weather. In stormy weather strong deformations in the concentration field occur.

When future airports are constructed, the access roads should be roofed. In future, arrival and departure halls should be designed in such a way that they are not placed on top of each other. Where space is lacking, efficient ventilation should be incorporated in the upper, covered road. Thus when there is no wind, pollution could be avoided in the area of access roads and parking garages; see Fig. 6 .

Similar situations can be found at many airports in the world, e.g. in Budapest, Hamburg or in New York, at the J.F. Kennedy airport; see Fig. 7 .

There is a significant concentration of unburned hydrocarbons and of nitrogen monoxide from buses and taxis near the terminals. In future, the feeder traffic must be provided with environmental friendly propulsion systems. This includes buses having engines powered by natural gas or hydrogen or electric motors, which could replace the old diesel technology in the apron area; see Fig. 8 ,

There were almost no detectable concentrations of air pollution at the edges of airports. Pollution peaks from road traffic could be detected, mainly from buses and partly from taxis. That means that airplanes produce less pollution than motor vehicle traffic. This is due to the good general technical state of engines through regular maintenance and inspection. Secondly the great distances cause dilution in the area of flight altitudes. While emissions emerging from motor vehicles are measured from a distance of $1-2 \mathrm{~m}$, there is a distance of at least $300 \mathrm{~m}$ between the turbo engines of an airplane and the measurement device.

\subsection{Weather dependency}

A strong weather dependency is shown. In summer the concentration of pollutants increases strongly on cloudy, calm and above all on mild rainy days. Also the smell of unburned hydrocarbons can be felt on these days.

The situation deteriorates in winter. At $2-3 \mathrm{C}^{\circ}$ with no wind and a cloudy sky, pollutants spread over the entire airport, with an average NO concentration of 100 to $200 \mathrm{ppb}$. Also at the far points, where traffic is still marginal, there is an NO concentration of $100 \mathrm{ppb}$. The concentration of pollutants increases in a significant way, especially in the terminal area. The base concentration of 300 to $400 \mathrm{ppb}$ near the access road reaches a level of 1,000 to $1,500 \mathrm{ppb}$. In the vicinity of bus stops and taxis with idling motors, the NO concentration reaches a level of 3,000 to $3,500 \mathrm{ppb}$. In winter, the $\mathrm{CO}$ concentration in this area increases to 2,000 to 3,000 ppb; see Fig. 9

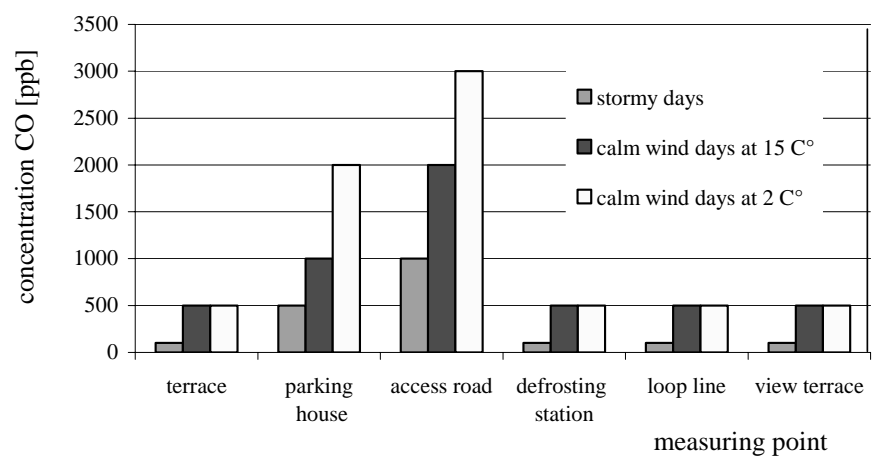

Fig. 9. $\mathrm{CO}$ concentration in the summer and in the winter

\subsection{Comparison with reference points in the city}

The concentrations of $\mathrm{CO}$ in the centre of big cities are between 0 and 1,500 ppb. At big crossings with a great number of motor vehicles with spark ignition engines up to $2,000 \mathrm{ppb}$ $\mathrm{CO}$ can be measured. Depending on traffic volume and weather conditions, the NO concentrations are between 100 and 500 ppb. The peak values are mostly produced by large commercial motor vehicles [7]. 
Especially high concentrations of pollutants can be measured under traffic bridges. However travelling at a moderate velocity with a speed of $30 \mathrm{~km} / \mathrm{h}$ leads to the decreasing of high concentrations with such unfavourable construction. With unlimited speed concentration peaks of 2,000 to 3,000 ppb CO and 500 to 600 ppb NO are soon reached.

At the margin of the city parks the measurable concentrations of $\mathrm{CO}$, NO and $\mathrm{HC}$ are very low; see Fig. 10

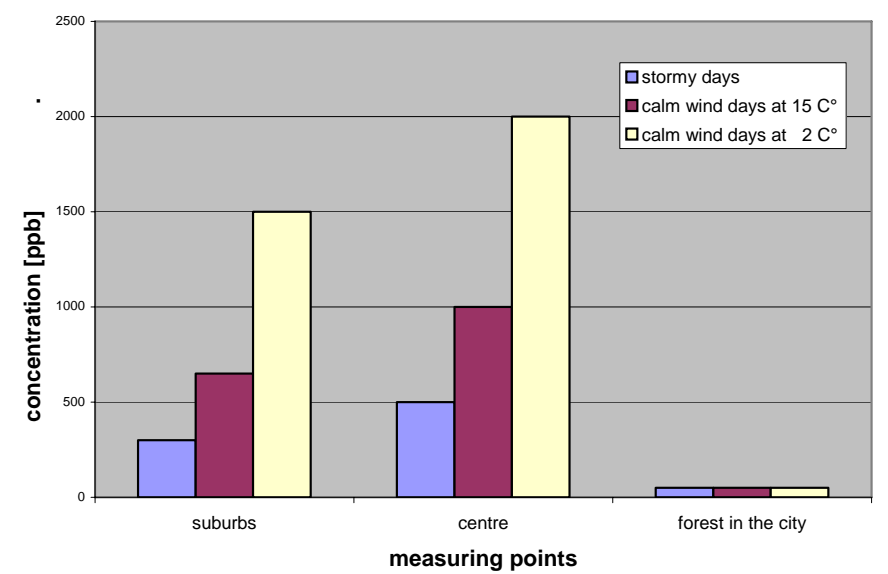

Fig. 10. CO concentration in the city

\section{Summary}

One of the most important problems in air traffic is the production of air pollutants at and near airports. The estimation can be made today with help of calculation methods and measuring techniques. In most cases, calculations lead to a usable approach, but considering the intensive development of air traffic, the measurement technologies are growing in importance.

To reduce the high concentration of pollutants in the atmosphere, airports have to consider four sources:

- fleet operation

- in-house energy supply

- ground feeder traffic by motor vehicles

- supply services for airports.

This system measures emissions during flight events (take off, landing and runway operations) from airplanes and from other airport specific sources. This very precise method makes it possible to compare this data with the calculated emissions of air pollutants in the big area of airports, and is much more correct, than the mathematical modelling of emissions and their distribution. The described method leads to a much improved accuracy of planning compared with the current situation.

\section{References}

1 Penner J E, Lister D H, Griggs D J, Dokken D J, Mc Farrland M, Aviation and the Global Atmosphere, Cambridge University Press, 1999.

2 DLR-Projektträger des BMBF: Umweltforschung, Schadstoff in der Luftfahrt. Abschlusskolloquium des BMBF-Verbundprogramms, 31. 03.1998.

3 Dräger X-am 7000, available at www.draeger-safety.com
4 Flughafen Düsseldorf Internationale: Nachbarschaftsdialog und Immissionsschutz, Februar 2007. Berechnung der Flugverkehrsemissionen am Flughafen Düsseldorf 1993-2006.

5 Dings J M W, Dijkstra W J, Wit R C N, European aviation emissions: Trends and attainable reductions. CE Centre for Energy Conservation and Environmental Technology, Delft, December, 1997. Report of background study.

6 Eickhoff W, Emissionen organisch-chemischer Verbindungen aus zivilen Flugzeugtriebwerken, 1998. Umweltplanung, Arbeits- und Umweltschutz, H. 252.

7 Hamburger Luftmessnetz. Ergebnisse 2007, Institut für Hygiene und Umwelt, available at www.hu.hamburg.de 